formation of the coal, and hence clearly within my terms of reference.

In the Memoir of the Geological Survey on the Coals of South Wales, it is pointed out that the anthracite condition, instead of being accompanied by a high ash-content-which is what might be expected if the ash ratio were determined simply by the reduction in the non-ash-is shown statistically to bear the reverse relationship. That is, the more anthracitic the coal, the lower the ash. From this it is argued that the anthracites of South Wales were formed of plant-constituents different from those contributing to the steam and house coals. This proposition gains no support from the study of the plants found in the associated measures, nor does it explain why the coals of other fields, composed in their various parts of very diverse constituents, do not exhibit the anthracite phase. But the ash question needs to be approached from another point of view. The ash of coal may, as I have shown elsewhere, be composed of three entirely distinct and chemically different materials. There may be (I) the mineral substances belonging to the plant-tissues; then (2) any detrital mineral substances washed or blown into the area of growing peat; and, finally, the sparry minerals located in the lumen of the cleat.

As to the first, I have long considered that the coal was in large measure deprived by leaching of much of its mineral substances; it is otherwise difficult to account for the almost total absence of potash. The second-detrital matter-is probably present in some though not in all coals; the high percentage of aluminium silicate is probably of this origin. But the third constituent-the sparry matter-may, both on a priori grounds and upon direct evidence, be assigned a very important rôle in the production of the ashes in most coals. When a coal with a strongly developed cleat is examined in large masses it is at once seen that the cleat spaces are of quite sensible width, and that they are occupied most commonly by a white crystalline deposit which may consist of either carbonate of iron or carbonate of lime, and there are also in many seams crystals of iron sulphide-either pyrites or marcasite. These sparry veins may be as much as $\frac{1}{10}$ th of an inch, or even more, in thickness, and they clearly constitute the principal contributors to the ash. It has been suggested that they are true components of the original peat, a proposition to which no botanist would assent, and it appears certain that the veins consist of material introduced by percolation from the overlying measures, subsequent to the production of the cleat. If that be so, it then will follow that the amount of the material present in coal must be in some direct proportion to the available cleat space, and if there is no cleat neither will there be any vein-stuff to contribute to the ash. It should be pointed out that ordinary bituminous coal broken. into minute dice and washed so as to remove any heavy mineral particles is found to contain a percentage of ash quite comparable with that of an average anthracite. It is to be concluded, therefore, that the variations of the ash contents of a coal are no indication of the plant-constituent of the coal.

I have sought to show how the concept of the Coal Measures with their sandstones, shales, and coal-seams accords entirely with what we know of modern swamps and deltas, and that just as each Coal Measure fact finds its illustration in modern conditions, so we may, inverting the method of inquiry, say that no noteworthy features of the modern swamps fail to find their exemplification in the ancient.

Even what may seem the most daring of my propositions-the seismic origin of abnormal "wash-outs" - finds, I cannot doubt, a full justification in what has been seen in the Sylhet region by Mr. Oldham, and in the Mississippi valley by Mr. Fuller, or in what can be inferred as a necessary subterranean accompaniment of these surface signs of great earthquake convulsions.

\title{
The Royal College of Science for Ireland.
}

TH E scientific public cannot but feel grave concern that the Royal College of Science for Ireland is at present closed, and its students are scattered in temporary accommodation. All interested in applied science will realise that this is a serious state of affairs, both as regards Ireland's industrial prosperity and scientific progress.

The College was founded nearly sixty years ago. It came into existence in 1865 as the result of a Treasury Minute of that year, which converted an existing institution - the Museum of Irish Industry and Government School of Science applied to Mining and the Arts - into the Royal College of Science. Sir Robert Kane-well known as the author of "The Industrial Resources of Ireland "-was appointed its first Dean.

The College was at first housed in premises in St. Stephen's Green, and as early as 1869 it had earned considerable reputation for itself as a school of science. Thus, the Commission on Science and Art in Ireland, of which Huxley and Haughton were members, reported in that year, that - "In "the Royal College of Science, Ireland possesses an institution which in the number of its professorships and general course of study is more complete as a pure school of science than anything of the kind existing in England or Scotland."

In its earlier years the College was under the administration of the Department of Science and Art; but in 1900 it was placed under the control of the newly created Department of Agriculture and Technical Instruction, a department which was largely the outcome of what was known as the Recess Committee, of which Sir Horace Plunkett was chairman and Mr. T. P. Gill secretary.

Under the enlightened administration of this Department, the College was greatly developed and extended, particularly in rendering it of more direct service to the industries and needs of the country. In the early days of the College, chief attention was devoted to such subjects as chemistry, physics, mathematics, geology, mining, engineering, and manufactures. Under the Department, however, not only were these activities extended, but also considerable developments were made in connexion with agriculture, which is the staple industry of the country. 
With the expansion of the teaching of applied science on so wide a scale, the accommodation in the existing buildings rapidly became wholly inadequate. Accordingly, the provision of new quarters became imperative, and under Act of Parliament in 1903 a government grant was made for this purpose. The magnificent new buildings on the present site in Upper Merrion Street were thus made possible, and the foundation stone was laid by King Edward VII. in 1904 . The buildings were opened by King George V. in July IgI $\mathrm{I}$, and in October of that year the College began work in its new laboratories.

The buildings (Fig. I), which were designed by Sir Aston Webb, occupy three sides of a quadrangle, and the numerous laboratories and lecture-rooms are laid out in a manner leaving nothing to be desired. Neither care nor expense has been spared in making the build- of the College to its new home, all the principal courses were extended to four years, an alteration which has been amply justified in the light of the results which have been attained. Broadly speaking, the curriculum is now arranged so that the first two years are devoted to work mainly of a mathematical and purely scientific character, while towards the end of the second year, and during the third and fourth years, attention is devoted largely to the applications of science, and to the professional aspects of the several subjects of study.

The courses in all cases involve very considerable use of laboratories and workshops, and close coordination between tuition in theory and laboratory work has been worked out carefully.

The work of the College is organised in three faculties--those of agriculture, applied chemistry, and

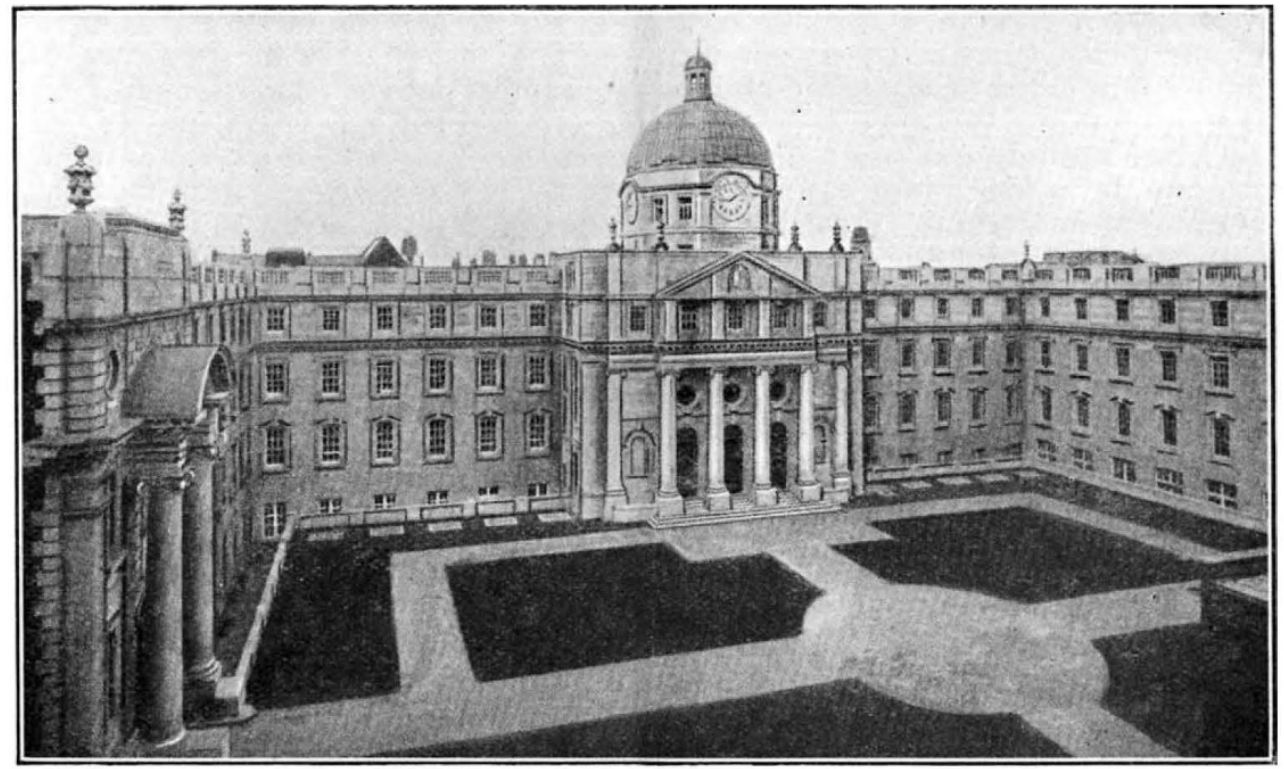

FIG. I.-Royal College of Science for Ireland.

ings and equipment perfectly suited for the work of the College. Many years have been spent in their completion, and they are among the best in the British Isles at the present time. The laboratories are replete with the most modern appliances and accessories, and the machines and apparatus installed have been chosen for their excellence from the world's markets.

In short, the College possesses the great advantage that its buildings and equipment in every detail are up-to-date, and both have been thoroughly laid out with the definite object of providing the means necessary for dealing efficiently with the courses of education undertaken. The College buildings also provide laboratory accommodation for the important work of the Plant Diseases and Seed Testing Division, and the Agricultural Analytical Station of the Department of Agriculture.

For some time it had become apparent that the three-year course, which until rgi had been required of the students taking the associateship, was inadequate to deal satisfactorily with a gradually extending curriculum. Accordingly, shortly after the removal engineering. In addition, there are four-year courses of study, in experimental science and in natural science, leading to industrial careers. The College also provides courses in science subjects for students who intend to become teachers in the technical and secondary schools of the country, and it is thus the keystone of the Department's scheme of technical and scientific education throughout Ireland.

Students who have successfully passed through one of the full courses of study are awarded the associateship of the College. Associates of at least three years' standing may proceed to the fellowship of the College, which is awarded for meritorious original scientific research or for contributing otherwise in a marked degree to the advancement of science.

There are professorships in agriculture, botany, chemistry, engineering, forestry, geology, mathematics, physics, and zoology; and lecturerships in agricultural botany, agricultural chemistry, bacteriology, organic chemistry, physical and metallurgical chemistry, engineering, horticulture, mathematics, and physics. Among the past professors are many well-known names, such as - Sir Robert Ball, Sir William Barrett, Sir

NO. 2772 , VOL. IIO] 
William Thiselton Dyer, Dr. A. C. Haddon, Sir Walter Hartley, E. Hull, Dr. G. T. Morgan, T. F. Pigott, and Sir Wyville J. Thomson.

Following upon the establishment of the College in its new buildings, there has been a steady and progressive increase in the number of its students, and its several courses of study are becoming appreciated more and more fully throughout the whole of Ireland. Moreover, the past students have been winning success in the several fields of industry and education for which their courses have fitted them.

In the Faculty of Agriculture the scientific courses given at the College have been the basis of considerable improvement in agricultural practice in the country, for in the majority of cases the young Irishmen who have attended these courses at the College have found their way into the service of the Department of Agriculture as Agricultural Instructors, located in various rural districts, where they act as scientific advisers to the farmers. Others put their knowledge to account in the management of large farms and estates.

In the Faculty of Applied Chemistry many highly trained young men have been turned out and have found scope for their training as assistants and research workers in many chemical industries, such as the manufacture of dyes, explosives, and synthetic drugs.

In the Faculty of Engineering the increase in the number of students following upon the development of the new laboratories has been specially marked, and already the demands for admission are taxing the accommodation to its utmost. The majority of these students find employment with the large engineering concerns in the British Isles; and prior to the present condition of depression, there was a regular demand cach year for capable students from some of the leading establishments. The output of the engineering and chemistry departments of the College should be of great and essential service to Ireland, if a policy of industrial reconstruction is undertaken.

The equipment of the College is excellently suited for active research in many directions. Indeed, already after a few years' occupation of the new premises, upwards of one hundred researches were in hand or had been carried out, many of them being on subjects of direct benefit to the industries of Ireland. While research thus holds a high place in its activities, the College is, nevertheless, specially noted for the thorough attention that is devoted to the effective teaching of its students. Its success is due to the devotion and energetic service of its able staff, as much as to the modern conditions under which their labours are carried out.

It would not only be a national calamity but also a matter of the greatest concern to progress in applied science if this great institution, that has taken many years of devoted service of its staff to bring to its present high standard of excellence, should be rendered unavailable for the young men and women of Ireland. It is, therefore, greatly to be hoped that the present difficulty will be but a passing cloud, and that the College will soon be permitted to reopen its doors, and will find its true place in the industrial development of Ireland.

\section{Obituary.}

Sir IsaAC Bayley Balfour, K.B.E., F.R.S.

I SAAC BAYLEY BALFOUR, son of the late Dr. 1 John Hutton Balfour, professor of botany in the University of Edinburgh from 1845 to $\mathrm{x} 879$, was born in Edinburgh on March 3I, I853. Educated at the Edinburgh Academy, then as now one of the foremost of British public schools, young Balfour proceeded to the University, in which he graduated as D.Sc. in the department (not yet a faculty) of physical and natural science. He also matriculated in the faculty of medicine, and while still an undergraduate in that faculty was so fortunate as to be attached to the party which in 1874 visited the island of Rodriguez to observe the transit of Venus.

Resuming his medical studies, Balfour graduated as M.B. with honours in 1877 , and thereafter continued his botanical studies in the Universities of Strasbourg and Würzburg. In 1879 he was appointed professor of botany in the University of Glasgow, and in $x 880$ undertook botanical survey operations in the island of Socotra. In 1883 he obtained the degree of M.D., being awarded a University gold medal for his thesis, and in 1884 he was elected Sherardian professor of botany at Oxford and given charge of the Oxford Botanic Garden, becoming at the same time a fellow of Magdalen. In 1888 he was elected professor of botany in the University of Edinburgh, in succession to the late Dr. Alexander Dickson, and was appointed King's Botanist for Scotland and Regius Keeper of the Royal Botanic
Garden. From these posts Balfour retired in March last after having held them, as his father did, for a period of thirty-four years.

If Balfour, as regards youthful environment, was fortunately situated, he showed at an early age that he had made good use of his opportunities. In 1874 Dr. J. D. Hooker, then director of $\mathrm{Kew}$, considered one of Balfour's letters from Rodriguez sufficiently interesting for communication to the Linnean Society. Among the results of this journey we owe to Balfour a finished study of the genus Halophila and an important contribution to the natural history of the difficult genus Pandanus. The elaboration of the material secured during his visit to Socotra involved sustained study for nearly eight years; the result was a work that has already become a floristic classic. But Balfour's systematic interest was equalled by that taken in economic questions, and his Socotran studies enabled him to determine the sources of more than one famous drug of which the geographical provenance was assured though the botanical origin was uncertain. From the outset of his career he realised the importance of historical study in the field of applied botany.

Short though Balfour's tenure of the Sherardian chair was, the success with which he discharged its duties led to results of permanent advantage to Oxford and to botany. Under his care the historic "Physick Garden " regained its old consequence. The part he played in the provision of an English version of De Bary's Fungi, Mycetozoa, and Bacteria earned for him 